\title{
The Abject as Body Language in Imre Kertész's Fateless and Alaine Polcz's One Woman in the War
}

\section{Edit Zsadányi}

\begin{abstract}
Among the various analyses that examine Imre Kertész's Fateless, little attention has been paid to the relationship between body and narrative. Using Julia Kristeva's concept of the abject, I focus on excerpts in the novel in which power breaches the boundaries of the protagonist's body, Gyuri Köves, as he endures detainment in various concentration camps. In this paper I argue that it is the dehumanized and abjectified body that rebels against totalitarianism by refusing to accept a deceptive survival scenario. When the perspective of death has been accepted, the concept of the abject paradoxically reveals that is the identity's inherent motherly aspect that is able to provide a human perspective to an abjectified person. After comparing excerpts in Fateless and One Woman in the War by Alaine Polcz, another narrative in which violence breaks the boundaries of the body, I will reach the conclusion that the body itself forms the final frontier of dictatorship. Once totalitarian dictatorship penetrates the body, it loses its influence over the victim as death offers a more humane, more bearable life. My examination of Fateless and One Woman in the War illustrates that it is the embodied mother in us which is able to refute totalitarianism and thereby empower an abjectified existence to become an empowering experience.
\end{abstract}

Keywords: Imre Kertész, narrative, Kristeva, abject, Holocaust, Alaine Polcz

Biography: Edit Zsadányi is an associate professor at the Cultural Studies Department of Eötvös Loránd University of Budapest. She was senior lecturer at the Finno-Ugric Department of the University of Groningen from 2009 to 2014. Her fields of research include women writers from the 20th century as well as modern and postmodern Hungarian and American literature, with a particular emphasis on cultural theory, narrative theories and Gender Studies. Zsadanyi.edit@btk.elte.hu

Imre Kertész's novel, Fateless [Sorstalanság], traces the Nazi practice of dehumanizing their victims by stripping people of their personal-cultural identities and debasing them to mere bodies. This process is depicted through the eyes of a fourteen-year-old Hungarian boy, Gyuri Köves, who experiences and eventually survives German concentration camps, where yellow stars, deportation, concentration camp prisoner uniforms, shaven heads and unhuman living conditions degrade people to mere biological creatures. After recounting the first days in Auschwitz, most of Gyuri Köves's first-person narrative focuses on how power keeps the 
survivors in constant danger of death and how it gets closer to them until it penetrates and tears through the boundaries of their bodies.

Little discussion has been conducted regarding the narration of physical processes and the relationship between body and narrative in Fateless. In this paper, I utilize Julia Kristeva's concept of the abject to examine moments in the novel in which power breaches the boundaries of the body and identity of the protagonist, thereby calling into question all mechanisms of symbolization, including the language of self-deception that surrounds the main character's identity both in Budapest and the concentration camp. I argue that it is the dehumanized and abjectified body that finally rebels against totalitarianism due to the fact that the abject experience possesses a potential for power by activating the forgotten motherly part of the personality precisely at the moment when culture and language desert the character. Paradoxically enough, it is only the remote, bodily voice of the mother that is able to offer a human perspective to an abjectified person by suggesting the acceptance of the perspective of death. By refusing the survival scenario, the motherly part of the personality resists the totalitarian power of the concentration camp which deceives the prisoners with the illusion of the possibility of survival.

Inspired by Mary Douglas's ideas regarding dirt and cleanliness, defilement and purity as culturally dependent concepts (Douglas 4-5), Julia Kristeva created the notion of the abject. According to Kristeva, abjects are end-products and by-products of the human body: bodily discharges, body fluids, fecal matter, blood and urine. Anxieties triggered by the abject are connected to protecting the boundaries of the self. As neither subjects nor objects, abjects embody the transition between the body and what is outside of it. In other word, the abject is a part of the body, yet does not belong there. While we spend our lives trying to get rid of them and treating them as objects outside of ourselves, the abject still disrupt our attempts at distancing ourselves and thus poses a constant threat to a consistent identity, a phenomenon which explains our anxieties regarding garbage and bodily discharges, our repulsion to fecal matter and urine and our disgust of blood and filth. Through socialization, we learn to mark the boundaries of the self and non-self by removing waste and creating a clean, obedient, lawabiding body at the cost of abjection, which can be traced back to the first rejection, the separation from the mother. Abjection, writes Kristeva, preserves some of this pre-objectal relationship, some of the non-evocable violence during which the body was separated from the mother's body. According to Kristeva, feelings of discomfort, dizziness and nausea when faced with the abject (blood, discharge, garbage or fecal matter) can be traced back to the ambivalence that surrounds the subject as it becomes an independent body, an object separated from the mother. In other words, repulsion at the abject is the lost memory of the mother's body and our disgust reveals an otherness that we cannot incorporate or identify with, one which predated, possessed and then created us as we had to overcome maternal possession at birth to later enter the order of symbolization and socialization (Kristeva 1-32, especially 9-10). End-products of the body not only resist symbolization, but also linguistic and - in this case - narrative representation, since discharges, diarrhea, excrement, urine, skin disease and weeping wounds are rarely chosen as the subject of literary narration. Fateless, however, challenges this narrative tradition: the subject of narration is the abject and the abjection of the self.

Before analyzing the role of the abject in the novel, it is important to refer to the abject as a social concept. Kristeva's original psychological concept of the abject has been expanded by cultural theorists, such as Iris Marion Young, Judith Butler and Hanjo Berresem, into a social 
concept, thereby extending the theory of the abject to a theory of abjection. In this case abjection refers to the cultural mechanisms that stigmatize with loathing and exclude certain groups or practices from the symbolic order. Iris Marion Young observes that xenophobia as abjection is present throughout the history of modern consciousness. Marginalized groups are often defined as ugly and fearsome, a condition which elicits aversion from the majority society. Since the abject does not respect borders, positions or rules, it creates ambiguity that threatens the borders of the subject. The subject reacts to the abject with loathing as a means of restoring the border separating the self from the other. Racism, sexism, homophobia, ageism and ableism are partly structured by abjection, the involuntary, unconscious judgment of ugliness and loathing. Young also emphasizes that the association between groups and abject matter is socially constructed and historically variable; however once the link is made, the theory of abjection can explain how these associations lock into the subject's identities and anxieties. As Young states, these associations "represent what lies just beyond the borders of the self, the subjects reacts with fear, nervousness, and aversion to members of these groups because they represent a threat to identity itself' (145). In Bodies That Matter: On the Discursive Limits of Sex (1993) Judith Butler broadens the concept of abjection by applying it not only to racial difference but also to sexual difference. When referring to the key factors that influence the culturally-governed materialization of bodies, Butler mentions the heterosexual imperatives that enable certain sexed identifications and foreclose others. Subjects are formed by these exclusionary mechanisms that require simultaneous production of abject beings. She states:

The abject designates here precisely those "unlivable' and 'uninhabitable' zones of social life which are nevertheless densely populated by those who do not enjoy the status of the subject, but those living under the sign of the 'unlivable' is required to circumscribe the domain of the subject .... In this sense, then, the subject is constituted through the force of exclusion and abjection, one which produces a constitutive outside to the subject, an abjected outside, which is, after all, 'inside' the subject as its own founding repudiation (Butler: 3).

Hanjo Berresem does not fully agree with Young or Butler about extending the notion of the abject into political fields since these theories do not take the disruptive materiality of the abject sufficiently into account. Berresem therefore claims that, "Although abjects may be included into a logics of cultural subversion, they remain disturbing on their own ground; the ground of matter and its organizations/disorganizations" (Berresem: 46). In agreement with Berresem's argument, my analysis will attempt to preserve both the material as well as the motherly aspect of the notion while emphasizing the social relevance of the abject. Beyond expressing the excluded and damaging position of the abject as is emphasized by the aforementioned theories, I would like to stress a special empowering potential of the abject experience.

Before continuing to my examination of Kertész's work, I will summarize the main ideas expressed by other scholars who have emphasized the importance skin possesses in identity construction, a realization that not only evolved into the concept of "skin-ego," but will additionally further clarify the significance of Kristeva's theory. In his post-World War II book, Az antiszemitizmus lélektana ['The Psychology of Anti-Semitism'], Imre Hermann demonstrates how the motif of the parasite emerged in works written by certain anti-Semitic authors. Hermann argues that, when faced with a powerful shock, the collective tends to act the same way an 
anxious person or monkey picks at their own hair, nails and wounds when sad or lonely, in other words, the collective tries rid itself of the perceived threat of parasitic Jews feasting on their skin (Hermann: 85). Apart from the context of the Holocaust, the idea that the subjectivity of the individual is closely related to the image of skin appears later in the psychoanalytical theory of Anzieu Didier, who (as a practicing psychologist) claimed that the skin had its own mental representation called the "skin-ego." Based on Didier's perspective, in a biological sense skin injuries expose the body to infections, while in the psychological sense injuring the mental skin has similar consequences. Penetrating the skin-ego consequently threatens the integrity and boundaries of the ego (Didier: 40). Didier's concept of the skin-ego has been applied by the American historian James M. Glass to his examination of exclusionary political and cultural operations. In his book Life Unworthy of Life: Racial Phobia and Mass Murder in Hitler's Germany, Glass expands Didier's idea of the skin-ego and refers to mass murder assisted by medical science as a "purification" rite that aims to cleanse the "skin-ego" of the collective while simultaneously fortifying their power and identity. In his further discussion of separation, the prohibition of conducting sexual relations with members of "inferior races," cleansing and murder, Glass states that all serve to preserve the boundaries between "clean" and "unclean." He argues that it is by these rites that the individual and the collective draw a sharp distinction between their healthy and integral ego and the "filthy," "infectious" Other (Glass: 39).

My analysis examining the relevance of the concrete body in Fateless is also informed by Boaz Neuman's historical research on the concept of the Volkskörper as manifested in the Nazi worldview. Neumann argues that Volkskörper and Fremdkörper are not abstract and metaphorical concepts in the Nazi worldview, but rather should be viewed as manifestations of actual and concrete bodies (154). Neumann asserts the following: "Auschwitz, where the Jewish ontology was erased, including its corporeal ontology, was where the Jewish body, the ultimate Fremdkörper, was flushed out of Volkskörper (178).

\section{The Voice of the Abject and the Language of the Body}

I examine the emergence of textual elements in Fateless that position Jews as parasites and will illustrate that - by virtue of appearing to identify with this state - the Jews depicted in Kertész's work actually deconstruct the myth. Allowing the "parasite pretext" to occasionally become visible in certain parts of the novel helps illuminate the irrational and lethal logic behind the reproduction of inherited and adopted preconceptions. As I have mentioned before, facing the abject is a traumatic experience, a circumstance which may explain why the majority of interpretations refrain from this type of analysis. The many scholars in Hungary who have studied the language of the novel often refer to the first half and final section of the novel, a fact that has reaped little comment regarding the narrative process of the deterioration of the body.

From the 1990s onward, interpretations of Fateless have primarily focused on methods for reinterpreting genres, the text's characteristic sentence structure, the relationship between the narrating "I" and the narrated "I" (Kovács: 73) and the correlations between irony and (Jewish) cultural identity (Schein: 109-111). For instance, Tamás Gábor Molnár claims that Fateless exhibits the narrative structure of the Bahtyinian adventure novel and views any deviations as an attempt to reinterpret that structure. Mihály Szegedy-Maszák discusses the novel in terms of the Bildungsroman while Péter Szirák utilizes terms related to 
the European tradition of the autobiographical and educational novel (Szirák: 22-27). In his monograph on Imre Kertész's works, Szirák repeatedly emphasizes the opinion that Fateless is not so much an accurate portrayal of Auschwitz as an attempt at language usage that reevaluates the way we relate to the Holocaust (Szirák 19). In his discussion of the chapter narrating the wait in the custom's house where Gyuri and his friends were detained, Mihály Szegedy-Maszák points out that in Gyuri's view inexplicable and pointless waiting turns human beings into animals (128). He quotes two sentences from the novel: "He raised, then slowly lowered his hands in a gesture of helplessness, while a thousand tiny quizzical wrinkles formed on his brow, giving him something of the look of a sad, trapped rodent" (50); and "in the end his hand merely fumbled, brushed, and scrabbled for a moment in the general area of his chest, like some big, sparsely haired spider or, even more, some kind of smaller sea monster that was, as it were, seeking the crevice that would allow it to scuttle under the jacket" (52). One could add that these are exactly the kinds of animals (spiders and rodents) to which anti-Semitic propaganda tends to compare Jews. Anna Menyhért highlights the section in which - after returning from the concentration camp-Gyuri Köves explains to the journalist how he gradually got used to the camp. She draws the conclusion that the victims' gradual adaptation represents a means of cooperation and participation in one's own systematic, carefully measured murder (Menyhért 127).

The volume Imre Kertész and Holocaust Literature (eds. Vasvári, Tötösy de Zepetnek 2005) places the works of Imre Kertész into international and interdisciplinary context. The papers in this collection approach the art and life of Imre Kertész from academic fields including literary studies, cultural studies, history, sociology and cinema studies. Julia Karolle, for instance, interprets Fateless as a special kind of historical fiction in which the author challenges historical authenticity versus historical facts and autobiography, thereby creating a new type of authenticity that is based on spriritual and moral truth (Karolle: 95). In a similar vein, Louise Vasvári interprets the novel as it evokes while simultaneously undermining the rhetorical and narrative tradition of Holocaust literature. Vasvári claims that the peculiar indifference of the teenage protagonist, the play upon authorial and narrative voice and the protagonist's provocative closing remarks concerning the happiness of the concentration camp function as a rebirth of Holocaust narrative (Vasvári: 266-268).

My analysis wishes to illustrate how the novel presents a body-language that speaks not just of the body but from the body by tracing how the text gives voice to the sick and repulsive abject and integrates it into a narrative culture. In my interpretation, Fateless shows how a narrative from and about the abject becomes a part of "high culture," while simultaneously invalidating the latter concept throughout the narrative process. In the second half of the novel, the diseased human body fills the role of the protagonist. What follows is a kind of corporal discourse as the sixth, seventh and eighth chapters describe hunger, diarrhea, scabs and infections caused by footwear, thereby presenting the detailed records of a man experiencing physical deterioration. In other words, we are reading an internal discourse dictated by the body: an authentic, calm and detached narration that closely relays the signs of the body.

The abject is almost always present in some shape or form in the narrative describing life in the concentration camp. The process of involuntary coexistence with the abject already begins on the train ride, when Gyuri Köves describes urinating and defecating into a bucket; upon his arrival at the camp, he initially refuses to eat the 
horrible soup, which he still considers to be filth at that point in his experience. Despite his best efforts, Gyuri's health becomes compromised in the camp; after working and living in the inhuman circumstances of the concentration camp in Zeitz, he abandons Bandi Citrom's survival advice regarding the need to keep himself thoroughly clean; when his wooden clogs rub his feet raw, the wounds consequently become infected. Bathing consequently becomes physically painful due to infections of the skin. The wooden clogs sticks to his foot like a new, painful and repulsive body part and he eventually resigns himself to not taking them off anymore, a circumstance that means Gyuri can no longer distance the abject from his own body. In other words, Gyuri can no longer maintain the boundaries of his body, just as he cannot when his skin becomes covered by scabs and wounds. Gyuri expresses his condition in the following manner while recounting his physical decline at the concentration camp in Zeitz.

Meanwhile those stiff uppers have long been chafing one's ankles and abraded countless sores on the softer tissues below them. Now, those sores by their very nature suppurate, and that pus is definitely sticky, with the result that it becomes impossible to free oneself from the clogs: they become stuck to the feet, veritably fused to them, rather like new body parts as it were. I wore them during the day and also wore them turning in to sleep, if only so as not to waste time when I got up, or to be more precise, jumped down from my bunk two, three, sometimes even four times during the night. That's all very well at night: after a bit of bother, stumbling and slipping around in the mud outside, one somehow manages to find one's way to the goal by the glare of the searchlights. But what is one supposed to do by day, exactly what, if the urge to empty one's bowels seizes one — as it inevitably will—in the work detail? (167) ${ }^{1}$

It is at this juncture in the novel that the abject topic of diarrhea is introduced. From this part on, the text often provides lengthy and detailed descriptions regarding the stages of physical deterioration. As both his skin and his identity become compromised, Gyuri's body begins to revolt; from this point forward, Gyuri Köves no longer listens to his friend's, Bandi Citrom's self-deceiving, survival- and cooperation-oriented advice. Instead, a different voice emerges from the position of the abject, a voice forged by Gyuri's resignation in the face of impending death that is only receptive to the signals of the body. In other words, Gyuri himself becomes Muselmann, the term the camps' jargon in reality as well as in the fictional world of Fateless uses to refer to the still living, dead bodies who are already heading towards death. As Manuela Consonni suggests, "the concentration camp was the place of abjection, and the most abject presence in it was the Muselmann" (246). Gyuri Köves surrenders and abandons his hope of a future and desire to survive exactly when he loses the last bastion of his identity: the integrity of the boundaries of his body. When he becomes so sick that he cannot even walk, Gyuri is taken to the hospital barracks by his friend, Bandi Citrom. While becoming increasingly ill, he realizes that he cannot shut out the violent forces that have already claimed his skin and penetrated his

\footnotetext{
${ }^{1}$ The provided page numbers refer to the published novels. In some excerpts where literal translation is needed for the sake of close textual analysis, I use translations by Éva Misits, who closely follows the structure of the original Hungarian text in her translation.
} 
body. The following example clearly shows that this realization forms a turning point in Gyuri's physical deterioration as well as in the process of understanding his situation. This is the point when the protagonist realizes that his body is swarming with parasites that not only live on his skin, but have also breached the boundaries of his body:

It was here that I learned about insects as well. I could never catch fleas: they were faster than I, which was quite reasonable since they were also better fed than I was. Now, louses I could catch with ease, only there was no point in catching them at all.... Still, I was never more surprised, shocked or horrified than when I suddenly felt a tingle on my hip and lifted the bandages to see that they were now on my flesh, feeding off my wounds. I tried to escape them, pick at them, push and gauge them out, to delay them or at least test their patience, and I will say I had never seen a struggle more hopeless, resistance more stubborn, more obscene, than this. After a while, I just gave up and merely watched their gluttony, their crawling and greed and appetite, their unabashed happiness - almost as though I had known that feeling at least a little. That's when I realized I could somewhat understand them, all things considered. In the end, I was almost relieved, my repulsion almost gone (182-183 emphasis E. Zs., translation by Éva Mislits).

[Itt ismerkedtem még meg továbbá igazán a férgekkel is. A bolhákat sehogy se tudtam megfogni: fürgébbek voltak, igen érthetöen, hisz elvégre jobban is tápláltak nálam. A tetveket már könnyen megfoghattam, csak hát ennek meg nem volt értelme. (...) Mégis, legjobban akkor lepödtem, hökkentem, majd rémültem is meg, mikor egyszerre csak csípömön éreztem a csiklandást, s a papirkötést fölemelve azt is láttam, hogy már a húsomon is ott vannak, s a sebemböl táplálkoznak. Próbáltam kapkodni, szabadulni, legalább innen kitúrni, kipiszkálni, legalább még egy kevéske türelemre, várakozásra szoritani öket s állithatom, sosem éreztem még küzdelmet kilátástalanabbnak, ellenállást konokabbnak, mondhatni szemérmetlenebbnek, mint ezt. Egy idö múltán föl is hagytam vele, s már csak néztem a falánkságot, ezt a nyüzsgést, mohóságot, étvágyat, ezt a leplezetlen boldogságot: bizonyosképp, mint hogyha valahonnan ismerném egy kissé. Akkor is vettem észre: némelyest meg tudom érteni öket, mindent megfontolva. Végül mármár megkönnyebbültem, már-már viszolygásom elmúlt] (233).

The following two sentences are worth repeating in order to focus upon how Kertész employs textual figures - mainly the structure of the sentence and an unusual word order - to create the process of abjection.

Still, I was never more surprised, shocked and horrified more than when I suddenly felt a tingle on my hip and lifted the paper bandages to see that they were now on my flesh, feeding off my wounds. I tried to escape them, pick at them, push and gauge them out, to delay them or at least test their patience and I will say I had never seen a struggle more hopeless, resistance more stubborn, more obscene, than this.

[Mégis, legjobban akkor lepödtem, hökkentem, majd rémültem is meg, mikor egyszerre csak csípömön éreztem a csiklandást, $s$ a papírkötést fölemelve azt is láttam, hogy már a húsomon is ott vannak, $s$ a sebemböl táplálkoznak. Próbáltam kapkodni, szabadulni, legalább innen kitúrni, kipiszkálni, legalább még egy kevéske türelemre, várakozásra szoritani öket s állíthatom, sosem éreztem még küzdelmet kilátástalanabbnak, ellenállást konokabbnak, mondhatni szemérmetlenebbnek, mint ezt](Emphasis, E. Zs.). 
In the first sentence, the word order, structural position and displacement of the Hungarian preverb meg seemingly conveys shock and confusion. It sounds odd in Hungarian that the preverb meg appears after the three verbs, but adding is meg after the third verb has an especially strange effect. This inversion of the usual word order textually illustrates the process of abjection whereby something that belongs (verb and preverb) become separated, yet not at the same time. While the is meg is part of the clause, it also appears as a strange (abject) attachment left clinging to the end of the clause. The next sentence describes the protagonist's final desperate, yet futile attempt to restore the boundaries of his body: the mess of cluttered infinitives that Kertész groups in this sentence actually foreshadows the failure of this attempt, which is followed by a string of longer words that establish a slower rhythm in the second half of the original Hungarian sentence.

Gyuri's struggle and subsequent fall into resignation would lend themselves to a symmetrical structural dynamic, were it not for another postponed clause, "than this" ['mint ezt'], which disrupts closure the same way the phrase, is meg, did. In fact, the two structures even rhyme with one another. Similarly, the double már-már ['almost'] in the Hungarian original sentence can also be considered the abject part of that: "Végül már-már megkönnyebbültem, már-már viszolygásom elmúlt" (Emphasis- E. Zs). "In the end, I almost felt relieved, even my sense of revulsion almost passed" (Emphasis, E. Zs.). These adverbs belong and yet do not belong; their presence adds extra information that destabilize the meaning of the statement since feeling almost relieved means that one is not relieved. From a visual standpoint, the adverbs are attached to the verbs, just as the abject is to the body. In the Hungarian sentence the attachments - in other words the spatial positions of the abjects - are very conspicuous since the word már is repeated four times. The slowing rhythm of the sentence suggests that the speaker finds death more soothing compared to struggling for survival. "That's when I realized I could somewhat understand them, all things considered. In the end, I was almost relieved, my repulsion almost gone." In its non-figurative meaning, the structure "all things considered" is also meaningful: "all things" meaning life and death. Relief could mean the acceptance of physical deterioration as well. Since power loses all influence once it breaches the integrity of the body, Gyuri no longer feels the need to partake in the survival method urged by his friend Bandi Citrom, namely, preserving the body by keeping it as clean and healthy as possible. Accepting the position of the abject and an imminent Death offer a more humane, more bearable life in the camp than a totalitarian dictatorship that encourages the twisted dream of survival until the very last moment. It must be emphasized that, as the text also makes it very evident, there is no more hope. Beyond this point, everything is filtered through and experienced within the perspective of impending death.

The abject also plays a very prominent role in another Hungarian novel that depicts events originating from World War II: Alaine Polcz's One Woman in the War. Blood, urine and fecal matter continuously appear in this novel, not a surprise given the fact that the latter half of the narrative recounts the symptoms (edema, leakage, fever, perspiration) the protagonist experiences due to diseases that were contracted due to multiple rapes in great detail. Louise $\mathrm{O}$. Vasvári's paper offers a detailed analysis of this work that links the concept of the body to the genre of autobiographies. At this point I will only draw a slight comparison to Kertész's novel by focusing on cases in which violence directly attacks the human body. Similar to Fateless, bodylanguage becomes the primary discourse related in the latter half of Polcz's novel. The two works can also be compared in terms of how their protagonists are not motivated by the hope of 
survival; since the future no longer matters to them as their horizons do not extend beyond the events and problems of the present, both narrators relate a series of hardships that make a swift death seem like salvation.

I will now highlight excerpts of physical violence to draw a parallel between these and the above quoted excerpts from Fateless, where power even penetrates the boundaries of the subjugated person's body. Abjects that resist narrative symbolization, such as filth, blood or discharge, are inseparable from the communication of these events, turning the excerpts into textual abjects - traumatic experiences that might trigger illness in readers.

I came to in the large interior room of the archdeacon. The glass broken, the windows barred, the bed empty: I lay on nothing but bare boards. One of the Russians was on top of me. I could hear a female voice echoing from the ceiling, "Mother, Mama!" it cried. Then I realized it was my voice, I was the one crying.

When I realized this, I stopped and lay still and quiet. My consciousness returned, but my other senses did not, as though I had become petrified or frozen. I was probably cold, naked from the waist down in that windowless, unheated room. I don't know how many Russians had their way with me afterwards, nor how many had before. At dawn, they left. I got up. It was very difficult to move. My head, my whole body was aching. I was bleeding profusely. I did not feel violated, but physically abused. This had nothing to do with embracing, with sex. It had nothing to do with anything. It was-I realize it just now, as I'm writing, that the word fits - vi-o-lation. That's what it was" (Translation by Eva Mislits, 110).

[Az esperes nagy belsö szobájában tértem magamhoz. Az üvegek kitörtek, az ablakok bedeszkázva, az ágyban nem volt semmi, csak a csupasz deszka, azon feküdtem. Az egyik orosz volt rajtam. Hallottam, ahogy a mennyezetröl egy nöi hang csapott le: anyu, anyuka! - kiabálta. Aztán rájöttem, hogy az én hangom az, én kiabálok. Mikor rájöttem, abbahagytam, csöndesen, mozdulatlanul feküdtem. A tudatommal nem tért vissza a testérzékelésem, mintha megdermedtem vagy kihültem volna. Az ablaktalan, fütetlen szobában, meztelen alsótesttel fázhattam is. Nem tudom, még hány orosz ment át rajtam azután, azt se, hogy azelött mennyi. Mikor hajnalodott, otthagytak. Fölkeltem, nagyon nehezen tudtam mozogni. Fájt a fejem, az egész testem. Erösen véreztem. Nem azt éreztem, hogy megeröszakoltak, hanem azt, hogy testileg bántalmaztak. Ennek semmi köze nem volt az öleléshez, sem a szexushoz. Semmihez se volt köze. Egyszerüen - most jövök rá, ahogy írom, hogy a szó pontos -: erö-szak. Az volt.]

The excerpt above does not relay feelings: the protagonist merely registers and reports what is happening to her. Perhaps the most shocking part of the narration is the unconscious cry for help, the voice calling the mother. This visceral cry is out of place in a dry narration that rarely uses direct quotation, thereby rendering it difficult for the reader to answer the essential question of "Who is speaking?" which is often posed by narrative theory. We do not exactly know who is speaking and from which vantage point since the cry precedes narrative consciousness. However, the last lines reflect upon this past event from the standpoint of the narrative present, while simultaneously making an attempt at symbolization: "It was-I realize it 
Zsadányi, Edit. “The Abject as Body Language in Imre Kertész's Fateless and Alaine Polcz's One Woman in the War." Hungarian Cultural Studies. e-Journal of the American Hungarian Educators Association, Volume 12 (2019) DOI: 10.5195/ahea.2019.352

just now, as I'm writing, that the word fits-vi-o-lation. That's what it was" ['Egyszerüen - most jövök rá, ahogy írom, hogy a szó pontos -: erö-szak. Az volt.']. Upon close inspection, parsing the word eröszak ['violation'] as 'erö-szak' ['vi-o-lation'] disrupts the reader's tendency to interpret the text automatically. The etymology of the word is now obscure, as the suffix that is added to erö ['power' or 'force'] is clearly not the equivalent of the modern Hungarian word, szak ['skill' or 'qualification']. For a few moments, the word echoes emptily, until the brief affirmation,"That's what it was," confirms the existence of this empty space. Quite paradoxically, breaking the work apart also emphasizes that making an association between power and ability is also possible, thus leading to the depiction of ability and the totality of power from the perspective of the subjected. This latter meaning comes far closer to the experience of the complete subjugation of the other, or-from the oppressed person's point of view-the experience of death.

Although Polcz's separation of the word, eröszak, implies that violation resists linguistic representation, the protagonist later attempts to present what has happened to her to her mother: "to nurse the sick" parallels the phrases used in the often-quoted final scene of Fateless, in which travelling home on a tram in Budapest, Gyuri becomes acquainted with a journalist who realizes that Gyuri has arrived directly from a concentration camp. The journalist tries to understand what Gyuri has gone through and attempts to relate Gyuri Köves' experiences. The following excerpt demonstrates how, from Gyuri's point of view, the journalist's use of language is absolutely inappropriate for expressing his experiences in the concentrations camp: "But in the present moment, he felt this wasn't as important as 'healing the bleeding wounds and punishing the perpetrators.' However, first and foremost, we must 'mobilize the public,' dispel the 'apathy, indifference or even doubt.' Clichés are no good, what we need, according to him, is to uncover the reasons, the truth, no matter how 'painful an ordeal' it is for us to face it" ['De jelen pillanatban, így tartotta, nem is ez a legfontosabb, hanem "a még vérzö sebek begyógyitása és a bünösök megbüntetése”. Mindenekelött is azonban "meg kell mozgatni a közvéleményt”, eloszlatni “a fásultságot, közönyt, sőt kételyt”. A közhelyek itt mit sem érnek, az okok, az igazság feltárására van, öszerinte, szükség, bármily "fájdalmas megpróbáltatás” is szembenéznünk vele'] (Translation by É. M., 319).

Although Gyuri Köves is engaged in a conversation with the journalist, we are not informed about his answers to the journalist; his first-person utterances are therefore intended for the implied reader. It is clear from their communication, however, that the journalist's vocabulary and the categories he has appropriated from European culture are completely incapable of describing what happened at the concentration camp. Given that the journalist's words are presented as a combination of reported speech and direct quotation, no difference is made between the information communicated. Instead, the speech situation keeps fluctuating as Gyuri Köves mediates some of the journalist's words in reported speech while he merely quotes others as though the words were alien to him as "to uncover...the truth" and "for us to face it" are conveyed in reported speech. The use of first-person plural in "for us to face [it]" allows the possibility that Gyuri Köves agrees, since the plural could be justified by either his or the journalist's presence. What is certain is that Gyuri Köves does not distance himself in this case from the speaker.

The phrases in quotation marks are, however, a different matter since they have been inserted into the narrator's speech and therefore cling to his utterances. In other words, quotation marks show that the journalist's words appear verbatim, but do not entirely belong to the 
speaker's discourse. It is also worth noting that these quoted phrases do not appear in a separate paragraph but still remain close to the voice of the protagonist, similar to foreign abject bodies that are inseparable from the narration as a whole. "Clichés are no good," can also be read ironically as a self-reflexive statement since the journalist does not seem to realize that he has just cited one of the biggest clichés to the returning protagonist. However, this humorous, rhetorical reading is then followed by another, more referential reading which teems with complex issues, in which clichés really are "no good" since they did nothing to keep the protagonist (or his several million fellow-sufferers) from being deported to the concentration camp; nor have they helped us, the readers. By means of this rhetorical twist, a curious disfiguration becomes apparent: words become bodies, just like people became bodies in the concentration camps. The most important interpretive possibility therefore lies in the primary meaning, the bare meaning: that words and culture did not matter and could not play a role in matters of life and death.

Utterances in quotation marks can also be considered another case of de-figuration in which it is the position of the word that matters, rather than its meaning. One simply cannot ignore the spatial-visual figures of these constant insertions since they are right there, belonging and yet not belonging to what is being said. Gyuri Köves cannot seem to get rid of them either, nor can he incorporate them into his own discourse. In other words, these words can be seen as repulsive foreign bodies in the narration. In this case, the visuality of the text replaces the abject positions: the words in quotation marks are stuck to the narrator's speech, thus, benevolent utterances of the journalist are placed in an abject position. Since Gyuri as narrator can neither identify with the quoted words nor incorporate them into his own discourse as reported speech, they remain attached to the main written discourse that mediates an internal point of view of foreign bodies that resemble abject elements. Similarly to the earlier analyzed narration in which vermin penetrates the body and the Nazis are put into the position of the abject, a new rolereversing, chiasmic figure is created: it is not the Jewish people who are forced into the role of the end-product, but rather the quoted texts. These oft- heard clichés and metaphors have thus been degraded into the discursive excrement of our Western culture. This may also be one of the reasons why metaphors are largely absent from both Fateless and One Woman in the War. Instead of indulging in metaphor, their unemotional and detached narration seems to question all aspects of culture. The visual and rhetorical effect of constant detachment forces our attention to focus on figures of the abject which thereby constantly remind us of the position the war's victims had been forced into. When readers identify with Gyuri's perspective, colloquial idioms and cliché metaphors such as "healing the bleeding wounds" may trigger repulsion and disgust, becoming abjects themselves. This is another case of disfiguration in which metaphors are contrasted with the representation of real bodies, "bleeding wounds" with bleeding wounds. This disfiguration invites us to realize that discourse operating with metaphors like this cannot represent the suffering body and soul.

When applying the theories of the abject and comparing excerpts taken from Fateless and One Woman in the War in which violence breaks the boundaries of the body, we are also confronted with the issue of the mother. Or, to put it more accurately, we are rather confronted by the painful absence of the mother. Why does the child, Gyuri, not recall his mother in his fantasy? The first sentence, "Today I did not go to school," evokes the first sentence of Albert Camus's The Stranger: "Today mother died." The two works are connected by the short statement with deictic word (today) as a starting sentence. Louise Vasvári and Ágnes Proksza 
Zsadányi, Edit. “The Abject as Body Language in Imre Kertész's Fateless and Alaine Polcz's One Woman in the War." Hungarian Cultural Studies. e-Journal of the American Hungarian Educators Association, Volume 12 (2019) DOI: $10.5195 /$ ahea.2019.352

highlight further parallels between The Stranger and Fateless. According to Proksza, the Hungarian novel reinterprets Camus's concept of the absurd (Proksza 119-121), while Vasvári (focusing on the indifference of the protagonists in the two texts) views Fateless as a new form of the existential novel (265-267). My reading draws a parallel between the two works on the basis of the figure of the mother. In Fateless, the mother is absent, but appears in the distance as an intertextual reference, as a lack; a double lack, in fact, since the referenced sentence is about the loss of the mother, suggesting that in the very first sentence of the Fateless, the moment the novel was born, the (lack of the) mother figure appears as a sort of palimpsest.

At the beginning of the book, we discover that Gyuri Köves lives with his father and stepmother, meaning his mother is not there. It is also obvious that the mother and son have a problematic relationship as the mother emotionally blackmails his son and blames him because he does not live together with her.

She says I 'belong' to her, to my mother. But as far as I know, the court ruled in favor of my father, and that means his decision is the one that counts. But my mother nagged me again this Sunday about how I want to live, because she thinks that all that matters is what I want, and if I love her. I told her, of course I loved her! But then my mother explained that to love is "to be attached to somebody", and from what she saw, I was more attached to my stepmother... After all, it's their argument. It would be very awkward for me to be the judge. And besides, I cannot rob my father, especially now that the poor man is in a labor camp. But I still felt uncomfortable when I got on the tram, because of course I'm attached to my mother, and of course it hurt that there was still nothing I could do for her (Emphasis by E.Zs, translation by Éva Mislits, 39-40).

['Azt mondja, őhozzá, az édesanyámhoz »tartozom«. De hát én úgy tudom, apámnak juttatott a bíróság, $s$ ilyenformán bizony az ö döntése az érvényes. Viszont anyám most vasárnap is arról faggatott, én hogyan akarnék élni - mert öszerinte meg egyedül csakis az én akaratom a fontos, meg az, hogy szeretem-e öt. Mondtam neki: hogyne szeretném! De anyám elmagyarázta, szeretni annyit tesz, hogy »ragaszkodunk valakihez«, márpedig ö úgy látja, mostohaanyámhoz ragaszkodom... Végtére is, ez az ö vitájuk. Ebben pedig feszélyezö dolog volna itélkeznem. Meg aztán különben is, nem lophatom meg apámat, $s$ hozzá épp most, mialatt szegény a munkatáborban van. De azért mégiscsak kényelmetlen érzéssel szálltam villamosra, mert persze, hogy anyámhoz ragaszkodom, s természetesen bántott, hogy ma sem tehettem érte semmit.']

The "[I] belong" in quotation marks does not belong to the text just as the phrase "to be attached to somebody" does not seem attached to the discursive style of the text that uses reported speech in order to mediate the mother's thoughts. The boy cannot identify with these phrases, he cannot translate them to his own language; the child's confusion and absurd situation he find himself in is evinced by the fact that he feels like a thief despite being the most exploited, despite having been cheated the most. In this argument between the parents, he also views himself as an object. The verb "rob" clearly marks the double role of subject and object; if we were to semantically supplement this short phrase, we would arrive at "I cannot rob my father of myself," meaning that the thief and the stolen object, the subject and object of the statement are 
one and the same. In this excerpt Gyuri is weirdly positioned as both subject and object, a key feature of the abject. Thus, Gyuri experiences a sort of abjection even before he and his fellows were abjectified by the Nazis. The phrase used by Gyuri's mother, "to be attached to somebody," as it appears in quoted form earlier in Gyuri's narration, visually represents a foreign body in his speech before the narration finally returns to his own speech, at which point he incorporates it as his own word and a direct expression of his affection: "because of course I'm attached to my mother." From this conversation between mother and son, we may conclude that their relationship is distant since, while referring to her, the protagonist keeps switching between reported speech, direct quotation and internal arguments with his mother and does not give any sign of affection from internal point of view. In fact, Gyuri only expresses his feelings when his mother is not present, when he bids her goodbye and continues to travel alone in the tram.

On the last page, we learn that the protagonist is on his way to see his mother, which allows us to interpret the novel as the story of a child who has been first separated from and then rejoined with the mother. This circumstance eerily illustrates how the experience of the abject does manage to invoke the figure of the mother; Gyuri's return home can also be interpreted as a type of unexpected reaction, one that resembles the protagonist's sudden cry for her mother in the rape scene in One Woman in the War. However, we do not learn if mother and son actually meet in the end (nor do we find out how his father's death is received) as the novel ends before the meeting. Nevertheless, the first and last pages both tell the story through images of the mother:

Yes, as I looked around this placid, twilit square, this street, weather-beaten yet full of a thousand promises, I was already feeling a growing and accumulating readiness to continue my uncontinuable life. My mother was waiting, and would no doubt greatly rejoice over me. I recollect that she had once conceived a plan that I should be an engineer, a doctor, or something like that. No doubt that is how it will be, just as she wished; there is nothing impossible that we do not live through naturally, and keeping a watch on me on my journey, like some inescapable trap, I already know there will be happiness. For even there, next to the chimneys, in the intervals between the torments, there was something that resembled happiness. Everyone asks only about the hardships and the 'atrocities,' whereas for me perhaps it is that experience which will remain the most memorable (262).

['Igen, ahogy körülnéztem ezen a szelíd, alkonyati téren, ezen a viharvert s mégis ezer igérettel teli utcán, máris éreztem, mint növekszik, mint gyülemlik bennem a készség: folytatni fogom folytathatatlan életemet. Anyám vár, s bizonyára igen megörvend majd nékem, szegény. Emlékszem, valaha az volt a terve, hogy mérnök, orvos vagy valami efféle legyek. Így is lesz minden bizonnyal, úgy, amint kívánja; nincs oly képtelenség, amit ne élnénk át természetesen, s utamon, máris tudom, ott leselkedik rám, mint valami kikerülhetetlen csapda, a boldogság. Hisz még ott, a kémények mellett is volt a kínok szünetében valami, ami a boldogsághoz hasonlitott'] (333).

It is important to note that Gyuri Köves first experiences a sort of vegetative, unconscious surge of life and then remembers his mother. From a different perspective, we could say that the figure of the mother is preceded by a sudden desire to live, similarly to how characters are 
summoned onto the stage in a musical play by their respective melodies. The protagonist senses the vegetative urge to live, and the image of the mother becomes linked to this urge as the mother's voice. The alter ego living in the subject as both same and other calls out to him, commands him and kindles his urge "to live." The shocking statement about the happiness of the concentration camps can be interpreted as listening to the inner figure of the mother that had forced us to live long before we made our decision. The triple alliteration of the original "folytatni fogom folytathatatlan életemet" ['I will continue my uncontinuable life'] plays on this maternal urge and the paradox of the impossibility of this urge. Gyuri Köves not only tells her thoughts but actually realizes them in speech: his above statement functions as a speech act. The triple alliteration is a continuous string, one continuous process: by saying it, he has already begun and continued the uncontinuable.

In the end, what can be learned from the notion of the abject? What can be learned in connection to freedom and resistance in these works by Imre Kertész and Alaine Polcz? When these novels are analyzed from the perspective of abjection, our determination to find some sign of resistance in these narratives is confronted by the sad conclusion that the final frontier of dictatorship is the body itself. Once a totalitarian dictatorship penetrates the body, it loses its influence over the victim as death offers a more humane, more bearable life. The severe violation of the boundaries of body and identity can invoke the forgotten maternal alter ego, to the point at which one turns away from culture and symbolization in favor of only listening to the presymbolic signals of the body. As the above analyses have shown, in extreme cases it is the embodied mother in us which is actually able to say no to totalitarianism. This is the reason why abjectified existence can become empowering experience. Those who have refused to participate in corrupting and collaborating tales relating survival, those who have faced death and invoked the lost voice of the mother, can still resist dictatorship.

Translated by Éva Misits 
Zsadányi, Edit. "The Abject as Body Language in Imre Kertész's Fateless and Alaine Polcz's One Woman in the War." Hungarian Cultural Studies. e-Journal of the American Hungarian Educators Association, Volume 12 (2019) DOI: 10.5195/ahea.2019.352

\section{Works Cited}

Berresem. Hanjo. 2007. "On the Matter of Abjection." In The Abject of Desire: The Aestheticization of the Unaesthetic in Contemporary Literature and Culture. Genus: Gender in Modern Culture. Ed. Konstanze Kutzbach, Monika Mueller. Amsterdam: Rodopi, 19-48. Web. 30 Nov. 2012.

Butler, Judith. 1993. Bodies That Matter: On the Discursive Limits of Sex. New York: Routledge.

Consonni, Manuela. 2009. "Primo Levi, Robert Antelme, and the Body of the Muselmann." Partial Answers: Journal of Literature and the History of Ideas. 7. 2009:2. 243-259. DOI: 10.1353/pan.0.0151

Didier, Anzieu. 1989. The Skin Ego. Trans.Chris Turner. New Haven and London: Yale UP.

Douglas, Mary. 1966. Purity and Danger: An Analysis of Concepts of Pollution and Taboo. New York: Routledge.

Glass, James M. 1997.“Life Unworthy of Life:” Racial Phobia and Mass Murder in Hitler's Germany. New York: Basic Books.

Hermann, Imre. 1990. Az antiszemitizmus lélektana ['The Psychology of Antisemitism']. Budapest: Bibliotheca, Cserépfalvi.

Kamarás, István. 2006. A sorstalanság sorsa ['The Fate of the Fateless']. Szombathely: Savaria UP, Print.

Karolle, Julia. 2005. “Imre Kertész's Fatelessness as Historical Fiction” In Imre Kertész and Holocaust Literature. Eds. Louise O. Vasvári, Steven Tötösy de Zepetnek. West Lafayette: Purdue UP, 2005, 89-96.

Kertész, Imre. 2002. Sorstalanság. Budapest: Magvető. . 2006. Fateless. Trans. Tim Wilkinson. London: Vintage Books.

Kovács, Béla Lóránt. 2002.”Az időbeliség tapasztalásának módosulásai Kertész Imre Sorstalanság című regényében" ['Ways of Experiencing Time in Imre Kertész's Fateless']. In Az értelmezés szükségessége. Tanulmányok Kertész Imréröl ['The Need for Interpretation'] Essays on Imre Kertész]. Ed. Tamás Scheibner and Zoltán Gábor Szücs. Budapest: L'Harmattan, 67-75.

Kristeva, Julia. 1982. Powers of Horror. An Essay on Abjection ['Pouvoirs de l'horreur']. Trans. Roudiez, Leon Samuel. New York: Columbia UP.

Menyhért Anna. 2003. “A kilátástalanság belátása: a belátás kilátástalansága. Kertész Imre: Sorstalanság” ['Acknowledging Hopelessness: The Hopelessness of Acknowledgment']. Egytucat. Kortárs magyar írók nöi szemmel ['A Dozen: Hungarian Contemporary Writers in Female Point of View’]. Ed. Tamás Gábor Molnár and Szilvia Sz. Molnár. Budapest: József Attila Kör - Kijárat Kiadó, 2003. 117-154. 
Zsadányi, Edit. "The Abject as Body Language in Imre Kertész's Fateless and Alaine Polcz's One Woman in the War." Hungarian Cultural Studies. e-Journal of the American Hungarian Educators Association, Volume 12 (2019) DOI: 10.5195/ahea.2019.352

Molnár, Gábor Tamás. 1996. "Fikcióalkotás és történelemszemlélet. Kertész Imre: Sorstalanság” ['Fictionality and Historical Views: Imre Kertész's Fateless']. Alföld 47.8 57-71.

Molnár, Sára. 2005. Ugyanegy téma variációi. Irónia és megszólitás Kertész prózájában ['Variations on the Same Topic. Irony and Invocation in Kertész' Prose Fiction']. Kolozsvár: Koinónia, 2005.

Neumann, Boaz. 2009. “The Phenomenology of the German People's Body (Volkskörper) and the Extermination of the Jewish Body". In New German Critique. 106, 36.1. 149-181.

Polcz, Alaine. 1991. Asszony a fronton. Budapest: Szépirodalmi. . 2002. One Woman in the War. Hungary 1944-1945. Trans. Albert Tezla. Budapest: CEU Press.

Proksza, Ágnes.2002. "Döntés és ítélet. Kertész Imre: Sorstalanság” ['Decision and Judgement: Imre Kertész’s Fateless']. In Az értelmezés szükségessége. Tanulmányok Kertész Imréröl ['The Need for Interpretation. Essays on Imre Kertész']. Ed. Tamás Scheibner and Zoltán Gábor Szücs. Budapest: L’Harmattan, 2002. 77-102.

Schein, Gábor. 2002. "Összekötni az összeköthetetlent” ['Connecting the Unconnectable']. Az értelmezés szükségessége. Tanulmányok Kertész Imréröl. [The Need for Interpretation. Essays on Imre Kertész] Ed. Tamás Scheibner and Zoltán Gábor Szücs. Budapest: L'Harmattan, 103-118.

Szegedy-Maszák Mihály. 2003. A kívülálló és az érintett: a megértés iróniája ['The Outsider and the Insider: The Irony of Understanding']. A megértés módozatai: fordítás és hatástörténet ['Manners of Understanding: Translation and History of Reception']. Budapest: Akadémiai, 125-132.

Szirák, Péter. 2003. Kertész Imre ['Imre Kertész']. Pozsony: Kalligram.

Szücs, Teri. 2009. "A Sorstalanság radikális tanúsága mint etikai kihívás” ['The Radical Moral of Fateless as Ethical Challenge']. In Irodalomtörténet ['Literary History'] 40.1: 58-60.

Vasvári, Louise O. 2010. "A töredezett (kulturális) test írása Polcz Alaine Asszony a fronton címú múvében" ['The Writing of the Fragmented Body in Alaine Polcz's One Woman in the War: Hungary 1944-1945']. In AHEA: E-Journal of the American Hungarian Educators Association 3. 1-16. Web. 14 Jan 2013. . 2005. “The Novelness of Imre Kertész’s Sorstalanság (Falelessness).” In Imre Kertész. and Holocaust Literature. Eds. Louise O. Vasvári, Steven Tötösy de Zepetnek. West Lafayette: Purdue UP, 2005, 256-270.

Vári, György. 2002. “Cselekményesítés, történelmi tapasztalat és a fenséges müvészete. " [The Plot, the Historical Experience and the Art of the Sublime. In Az értelmezés szükségessége. Tanulmányok Kertész Imréröl. [The Need for Interpretation. Essays on Imre Kertész] Ed. Tamás Scheibner and Zoltán Gábor Szücs. Budapest: L’Harmattan, 119-136.

Young, Iris Marion. 1990. Justice and the Politics of Difference. Princeton: Princeton UP, 1990. 